\title{
Plaidoyer pour un soutien fort et durable à la recherche en radiobiologie pour optimiser la radioprotection
}

La radiobiologie $(\mathrm{RB})$ est avec l'épidémiologie et la dosimétrie au coeur de la radioprotection depuis des dizaines d'années (Bourguignon et al., 2017). Puisque les être humains sont exposés de façon continue aux rayonnements ionisants (RI) d'origines variées naturelles et artificielles avec une tendance à l'augmentation des doses notamment aux patients (UNSCEAR, 2008; European Dose Datamed II, 2014), il y a un besoin persistant de mise à jour des données de la radiobiologie. Outre cette utilisation défensive de la $\mathrm{RB}$ pour la radioprotection, la RB apporte beaucoup plus à la société et en conséquence doit être développée davantage : «La radiobiologie a fait et continue de faire des contributions critiques à la science » (Kirsch et al., 2017).

La RB est la connaissance des effets des RI sur la matière vivante (cellules, tissus et organisme) et des mécanismes réactionnels et de défense en ce qui concerne le maintien des structures et des fonctionnements (Tubiana, 2008 ; Hall et Giaccia, 2012). La recherche fondamentale en RB a apporté des avancées significatives sur les mécanismes moléculaires (Ravanat, 2018), cellulaires et tissulaires des effets immédiats des RI et sur les réponses subséquentes retardées. Les cellules ne répondent pas passivement mais activement et réparent de façon dynamique les lésions, notamment celles de l'ADN, avec plus ou moins de succès. En cas d'échec de la réparation de l'ADN, la transformation cellulaire peut conduire à un cancer mais heureusement la mort ultime des cellules protège l'oganisme contre les tranformations cellulaires. Au niveau tissulaire, les cellules communiquent ensemble et échangent des signaux critiques en ce qui concerne l'évolution des cellules et des tissus après irradiation. Cependant trop de morts cellulaires peut conduire à la dégénérescence des tissus et au vieillissement.

La compréhension des mécanismes intimes des effets des RI a conduit historiquement à la radiothérapie qui est aujourd'hui une technique majeure de traitement des cancers puisque plus de $50 \%$ des patients cancéreux bénéficient de la radiothérapie avec un taux de succès d'environ $80 \%$, et ce, à faible coût $(10 \%$ du coût total du cancer). Comme inconvénients de ce traitement puissant, des effets secondaires et des complications (Thellier, 2019a, 2019b) ne sont pas si rares alors même qu'il n'y a pas eu d'erreur dans la délivrance de la dose et dans la balistique de l'irradiation (Foray et al., 2016). Les seconds cancers primaires ne sont pas rares et concernent de 8 à $10 \%$ des patients traités (Cosset et al., 2018) et des effets cardiovasculaires sont suspectés et recherchés. La recherche en RB est nécessaire pour comprendre pourquoi des effets secondaires et des complications surviennnent afin de les prévenir et de les traiter efficacement. Une réponse individuelle anormale aux fortes doses de RI, décrite depuis le début $\mathrm{du} \mathrm{XX}^{\mathrm{e}}$ siècle, peut expliquer pour une grande part ces effets secondaires anormaux et ces complications (Foray et al., 2016). De nouveaux paradigmes en radiothérapie, par exemple la technique Flash, diffèrent signifcativement des paradigmes classiques et exigent de nouvelles investigations de RB afin de comprendre précisément la séquence des événements.

L'évidence d'une réponse anormale aux RI observée jusqu'à $20 \%$ de la population est maintenant reconnue (Foray et al., 2016; Applegate et al., 2020) et des études approfondies sont plus que jamais nécessaires pour étudier les trois résultats possibles dus : (1) à la radiosensibilité, c'est à dire les complications et les effets secondaires de la radiothérapie, (2) la radiosusceptibilité au cancer et (3) la radiodégénérescence des tissus, par exemple les cataractes.

Aujourd'hui la majorité des expostions aux RI surviennnent aux faibles doses et leurs effets ne sont pas compris en profondeur, pas plus que les conséquences réelles des expositions médicales. Les effets des faibles doses ont été pris en compte jusqu'ici par l'épidémiologie mais les études épidémiologiques chez les travailleurs ignorent toujours les doses médicales reçues par ces travailleurs, qui peuvent être plus élevées que leurs doses professionnelles. De plus, la puissance statistique des études épidémiologiques restera limitée, à moins que de nouvelles études soient basées sur des cohortes sélectionnées sur la base de biomarqueurs, par exemple en prenant en compte la réponse individuelle aux RI. À quand des études chez les femmes à risque familial de cancer du sein et exposées de façon régulière aux RI par mammographie de dépistage, ou chez les enfants qui présentent un cancer du cerveau ou une leucémie après exposition(s) médicale(s) aux rayons X du scanner (les études européennes EPI-CT d'épidémiologie classique dont les résultats officiels sont très attendus depuis longtemps) ou chez les patients nonfumeurs avec un cancer du poumon? L'hypothèse selon laquelle les mauvaises conséquences de ces situations sont liées à une réponse individuelle anormale aux RI doit impérativement être explorée.

L'évidence émergente que les mécanismes des effets toxiques des pesticides et des métaux lourds sont leurs génotoxicités, aggravées par une déficience de la réponse aux dommages de l'ADN, ouvre la voie à une approche compréhensive du risque combiné (exposome). Une réponse anormale à la génotoxicité peut constituer un statut particulier où de faibles doses qui, prises isolément, seraient à peine considérées, additionnent leur génotoxicité et deviennent alors une vraie préoccupation.

Des techniques récentes d'investigation apportent des éclairages significatifs dans l'évaluation des mécanismes cellulaires, comme par exemple l'immunofluorescence qui permet de suivre des protéines dans leur voyage intracellulaire et particulièrement permet de savoir si la bonne protéine est en bonne quantité au bon endroit au bon moment (Granzotto et al., 2016). 
Ces techniques ont des bénéfices significatifs et des promesses potentielles mais leur succés soulève des défis importants puisque nous sommes juste au début de l'utilisation en pratique médicale de la connaissance des cinétiques protéiques, notamment pour la signalisation et la réparation des lésions de l'ADN et de l'expression et de la régulation du génome. Les perturbations cellulaires liées aux expositions aux RI ex vivo et in vitro peuvent être observées en profondeur et apparaitre très utiles pour explorer le fonctionnement cellulaire, sa normalité ou non.

Ainsi les sujets principaux d'intérêt dans le domaine de la radiobiologie sont ceux dans lesquels de nouvelles investigations et leurs résultats peuvent changer la prise en charge des personnes, des travailleurs et tout spécialement des patients qui sont de loin les plus exposés au RI (pour leur bénéfice si l'exposition est justifiée). Le potentiel de ces investigations et les résultats attendus sont nombreux et on peut entrevoir qu'ils doivent faire partie d'une médecine personnalisée appropriée avec des résultats critiques en termes de médecine préventive.

Dès lors, il est bien regrettable de constater que les ressources attribuées à la radiobiologie sont en constant déclin pendant cette dernière décennie. Dans une prise de position récente publiée dans le Journal du National Cancer Institute et intitulée « Le futur de la radiobiologie », DG. Kirsch et al. déclaraient : «Pour maintenir sa pertinence scientifique et clinique, le domaine de la biologie des radiations doit surmonter des défis de main d'oeuvre, de formation et du financement de la recherche » (Kirsch et al., 2017).

Il est trop simple de penser ou de dire que cette situation résulte d'un contexte global de restriction budgétaire. C'est principalement parce que les perceptions au sujet des RI sont nombreuses et fort erronées : tout ce qui touche au nucléaire est considéré comme maléfique, la radioactivité naturelle n'est pas préocupante et les expositions médicales sont bénéfiques (Nasr et al., 2019). Rien de plus faux puisque les expositions humaines aux RI sont minimales/négligeables, les expositions au gaz naturel radon peuvent être significatives mais uniquement dans des pièces mal ventilées dans quelques régions géographiques et les expositions médicales sont de loin les plus importantes pour le nombre des personnes exposées (des millions) et les doses. Les manipulations de l'opinion publique - qui influencent les décideurs - ont contribué à maintenir ces confusions depuis des dizaines d'années. Le risque de l'exposition aux RI est considéré à tort comme faible en l'absence d'accident. En conséquence, l'accent a été mis sur la sûreté nucléaire et pas sur la radioprotection. Le but de la radioprotection est vraiment mal compris. Vous pouvez supprimer le nucléaire, la radiobiologie et la radioprotection existeront toujours. C'est une question psychosociale dramatique !

C'est donc notre responsabilité d'identifier les questions clés de la radiobiologie qui doivent être considérées comme des priorités parce que les résulats apportés à ces questions fondamentales changeront notre compréhension du monde et la prise en charge de millions de patients et de personnes. Nous avons mis en exergue toutes ces situations où la radioprotection est une question sur la base des découvertes de la radiobologie. Nous espérons - ne dit-on pas - qu'un problème bien posé est à moitié résolu!

Nous ouvrons le journal Radioprotection à des articles destinés à encourager la communauté de la radiobiologie et au-delà les praticiens médicaux et aux utilisateurs de RI à échanger idées et recherches pertinentes pour démontrer aux autorités compétentes la nécessité d'investir davantage dans la recherche en radiobiologie et dans ses applications.

En conclusion, la recherche en radiobiologie est en crise et ceci n'est ni vu ni pris en considération. La radiobiologie et la radioprotection ont besoin d'un support fort et durable parce qu'elles sont largement méconnues et mal comprises bien qu'elles portent des questions majeures de santé publique et des questions sociétales. Les financements nationaux et européens devraient être significativement et durablement augmentés pour s'attaquer aux problèmes essentiels, et le plus important d'entre eux est la réponse individuelle aux rayonnements ionisants, tout spécialement dans le contexte des expositions médicales et de la médecine personnalisée.

\section{Advocacy for a strong and sustainable support to radiation biology research in order to optimize radiological protection}

Radiation biology (RB) together with epidemiology and dosimetry has been at the heart of radiological protection for decades now (Bourguignon et al., 2017). Since humans are continuously exposed to ionizing radiation (IR) from various natural and artificial sources with a trend of increasing doses notably in patients (UNSCEAR, 2008; European Dose Datamed II, 2014) the need for updated RB remains. Besides this defensive use of RB for radiological protection RB brings much more to our society and consequently needs to be further developped. "The field of radiobiology has made and continues to make critical contributions to science" (Kirsch et al., 2017).

$\mathrm{RB}$ is the knowledge of the effects of IR on living matter and how cells, tissues and body react and defend their structures and functioning (Tubiana, 2008; Hall and Giaccia, 2012). Fundamental RB research has brought significant insights into the molecular (Ravanat, 2018), cellular and tissular mechanisms of the immediate effects of IR and the subsequent delayed responses. Cells do not passively respond but actively and dynamiccaly repair the lesions notably the DNA insults with more or less success. In case of failure of DNA repair, cell transformation may lead to cancer but hopefully the ultimate death of cells protects the organism against cell transformation. At the tissular level cells communicate together and exchange signals which are critical regarding the evolution of both cells and tissues after irradiation. However, too many cell deaths may lead to tissue degeneration and aging.

The comprehension of intrinsic basic mechanisms of the effects of IR historically paved the way to radiation therapy which is nowadays a major technique of treatment of cancers since more than $50 \%$ of cancer patients benefit from radiotherapy with a 
success rate of about $80 \%$ and at a low cost $(10 \%$ of the whole financial burden of cancer). As a drawback of this powerful treatment side effets and complications (Thellier, 2019a, 2019b) are not so rare although there are no errors in dose delivery and ballistics of irradiation (Foray et al., 2016). Second primary cancers are not so rare ranging from 8 to $10 \%$ of treated patients (Cosset et al., 2018) and cardiovascular effects are suspected and investigated. RB research is needed to understand why these side effects and complications do occur in order to either prevent them or to treat them efficiently. Significantly abnormal individual responses to high doses of IR, described since the beginning of the XXth century, may explain for a large part these abnormal side effects and complications (Foray et al., 2016). New paradigms in radiotherapy such as the Flash technique which differ signifcantly from the classical ones require new RB investigations in order to understand precisely the sequence of events.

The evidence of an abnormal response to IR in up to $20 \%$ of the population is now recognized (Foray et al., 2016; Applegate et al., 2020) and extensive studies are more than ever necessary to address the three possible outcomes due to: (1) radiosensitivty, $i$. e., complications and side effects of radiotherapy, (2) radiosusceptibility to cancer and (3) radiodegeneration of tissues, e.g., cataract.

Today most exposures to IR occur at low doses and their effects are not deeply understood, not more than the real consequences of medical exposures. The effects of low doses have been considered so far mostly by epidemiology but the epidemiology studies in workers still continue to ignore medical doses which may be larger than the occupational doses received. Furthermore the statistical power of the epidemiology studies will remain limited unless new studies are based on cohorts selected on the basis of biomarkers, e.g., by taking into account the individual response to IR. What about studies in women with family risk of breast cancer and continuously exposed to IR by mammography screening, or in children with a brain cancer or a leukemia discovered after medical CT exposures (EPI-CT studies which standard epidemiology results are pending) or in non smokers persons with lung cancer? The hypothesis that the poor outcome in these situations is related to an abnormal individual response to IR should be investigated.

The emerging evidence that the mechanisms of the toxical effects of pesticide or heavy metals are their genotoxicity aggravated by a potential impaiment of the DNA damage response opens the way to a comprehensive approach of combined risk (exposome). An abnormal individual response to genotoxicity may constitute a peculiar status where low doses which would be barely considered alone sum up their genotoxicity and thus become a real concern.

Recent techniques of investigations have brought quite significant insights into the evaluation of cell mechanisms, e.g., immunofluorescence permit to follow specific proteins during their intracellular journey and especially to know if the right protein is in the right amount at the right place at the right time (Granzotto et al., 2016).

These techniques have significant benefits or potential promises but their success raise significant challenges since we are just at the beginning of the practical medical use of both molecular kinetics inside the cell notably for both signalisation and repair of DNA lesions and genome expression and regulation. Cellular disturbances by exposures to IR ex vivo and in vitro can be investigated in depth and appear quite useful to explore cell functionaing and its normalcy or not.

Then the main topics of interest in the field of RB are those in which new investigations and results may challenge the approach and the management of persons, workers and especially of patients who are the most exposed to IR (for their benefit if exposure is justified). The potential of these investigations and results are numerous and one can foresee that they must be part of an appropriate personnalized medicine with critical outcomes in terms of preventive medicine.

Thus it is very unfortunate that the ressources allocated to RB have steadily declined in the past decade. DG. Kirsch et al. stated in a recent position paper published in the Journal of the National Cancer Institute and entitled "The future of Radiobiology": "To maintain scientific and clinical relevance, the field of radiation biology must overcome challenges in research workforce, training and funding" (Kirsch et al., 2017).

It is too simple to think or say that this situation results from a global context of scarce public ressources. This is mostly because the perceptions regarding ionizing radiations (IR) are numerous and quite wrong: whatever nuclear is considered to be the devil, natural radioactivity is not of a concern and medical exposures are beneficial (Nasr et al., 2019). Nothing more wrong since the exposures to IR of humans by nuclear activities are minimal/negligible, exposures to natural radon may be significant but only in poorly ventilated rooms in some geographic regions and medical exposures are by far the most important ones (in the number of exposed people (millions) and in doses). Public opinion manipulations - influencing deciders - have contributed to maintain such confusion for decades. The risk of exposure to IR is wrongly considered to be low in the absence of accident. Thus the focus has been on nuclear safety and not on radiological protection. The purpose of radiological protection is quite misundertood. Would you stop nuclear, RB and radiological protection will always remain. It is a dramatic psycho-social issue!

Therefore it is our responsibility to identify the key issues in RB that must be considered as priorities because the results to these right questions will change our comprehension of the living world and the management of million of patients and people. We have highlighted above so many situations where radiological protection is an issue on the basis of radiation biology findings. We hope, don't we say, that a well-posed problem is half solved!

We open the journal Radioprotection to papers to encourage the exchange of pertinent research and ideas within the RB community and beyond with medical practitioners and users of IR and to demonstrate to relevant authorities the necessity to further invest in RB research and applications.

In conclusion research in radiation biology is in crisis and this is not seen or considered. Radiation biology and radiological protection needs a strong and sustainable support because they are still largely unknown and misunderstood although they carry critical public health and societal issues. Both national and European financing should be significantly and sustainably increased to tackle the main issues, the critical one being the individual response to ionizing radiation especially in the context of medical exposures and personnalized medicine. 


\title{
Références
}

Applegate KE, et al. 2020. Individual response of humans to ionizing radiation: governing factors and importance for radiological protection. Radiat. Environ. Biophys. 59: 185-209.

Bourguignon M, Bérard P, Bertho JM, Farah J, Mercat C, Radioprotection Editorial Board. 2017. What's next in Radioprotection? Radioprotection 52(1): 21-28.

Cosset JM, Hetnal M, Chargari C. 2018. Second cancers after radiotherapy: update and recommandations. Radioprotection 53(2): 101-105. European Dose Datamed II Project Report. 2014. European Commission. Radiat. Protect. 180.

Foray N, et al. 2016. Individual response to ionizing radiation. Mutat. Res. 770: 369-386.

Granzotto A, et al. 2016. Influence of nucleoshuttling of the ATM protein in the healthy tissues response to radiation therapy: toward a molecular classification of human radiosensitivity. Int. J. Radiat. Oncol. Biol. Phys. 94(3): 450-460.

Hall EJ, Giaccia AJ. 2012. Radiobiology for the radiologist, 7th edition. USA: Lippincott Williams and Wilkins.

Kirsch DG, et al. 2017. The future of Radiobiology. JNCI. https://doi.org/10.1093/jnci/djx213.

Nasr RY, et al. 2019. Analysis of public perception about ionizing radiation. Radioprotection 54(4): $289-293$.

Ravanat JL. 2018. Endogenous natural and radiation-induced DNA lesions: differences and similarities and possible implications for human health and radiological protection. Radioprotection 53(4): 241-248.

Thellier S. 2019a. Analyse des risques en radiothérapie. Partie 1: forces et faiblesses de la méthode AMDEC. Radioprotection 54(1): 11-19.

Thellier S. 2019b. Analyse des risques en radiothérapie. Partie $2:$ des modes de défaillance aux modes de réussite, un changement de paradigme. Radioprotection 54(1): 21-30.

Tubiana M. 2008. Radiobiologie. Radiothérapie et radioprotection. Bases fondamentales. Herman Éditeurs.

UNSCEAR. 2008. Estimates of worldwide average exposures (Vol. 1 Annex B).

\author{
M. Bourguignon ${ }^{*}$ \\ Editeur en Chef \\ *michel.bourguignon@irsn.fr
}

